\title{
The Effect of Work Environment and Achievement Motivation on Performances of Lecturers Guidance and Counseling Department at Medan State University
}

\author{
$1^{\text {st }}$ Nasrun $^{1}, 2^{\text {nd }}$ Erwita Ika Violina ${ }^{2}, 3 r^{\text {d }}$ Nani Barorah Nasution ${ }^{3}, 4^{\text {th }}$ Dody Feliks Pandimun \\ Ambarita, $5^{\text {th }}$ Husna Parluhutan Tambunan \\ \{nasrun.nst@gmail.com ${ }^{1}$, erwitaika@unimed.ac.id ${ }^{2}$, nanibarorah@gmail.com ${ }^{3}$ \}
}

Department of Guidance and Counseling, Faculty of Science Education, Universitas Negeri Medan, J1. Willem Iskandar Pasar V Medan Estate, Medan Tembung 20221, Indonesia ${ }^{1,2,3}$

\begin{abstract}
The purposes of this research are to know the effect of work environment and achievement motivation on performances. This study used survey method with path analysis. The population and sample were 25 lecturers. The instruments were questionnaires compiled in the form of positive statements based on Likert scale model. Product Moment Correlation formula is used to calculate the validity and Alpha Cronbach formula is used to calculate reliability. The findings represented that work environment can directly affect achievement motivation with path coefficient of 0.444 , work environment can directly affect performances with path coefficient of 0.272 and achievement motivation can directly affect performances with path coefficient of 0.479 .
\end{abstract}

Keywords: Work Environment, Achievement Motivation, Performances.

\section{Introduction}

University as one of the formal educational institutions has a goal to produce quality human resources who have the knowledge, skills, and technology needed by the world of work. The university has a mission to achieve national education goals as stated in Government Regulation Number 60 Year 1999, in section 2 namely: (1) preparing college students to become members of the community who have academic and/ or professional abilities who can apply, develop and/ or create science and technology, (2) develop and disseminate science and technology and seek its use to improve people's lives and enrich national culture. This shows the role of university is very important seen from the mission it carries, namely in the form of enlightenment to the life of the community and nation [1].

Universitas Negeri Medan is one of the state universities that has the aim to prepare human resources to obtain the knowledge and abilities needed by the community. To realize this, the lecturers as the main actors in managing learning in university are expected to be able to prepare college students to master, apply, develop, disseminate science and technology obtained in university. But in reality, based on the results of monitoring and evaluation in 2009 , it can be seen that the performances of lecturers have not been optimal in carrying out education, research and community service. In line with the United Nations (UN) Agency Report for the field of education, United Nation Educational Scientific and Cultural Organization (2007) showed that Indonesia's ranking in terms of education dropped from rank 
58 to 62 among 130 countries in the world. Indonesia's Education Development Index (EDI) is 0.935, below Malaysia (0.945) and Brunei Darussalam (0.965) [2]. The low quality of Indonesian human resources is a reflection of the low performances of lecturers at university.

The low performances of lecturers are caused by various factors. One thing that needs attention is achievement motivation. Lecturers who have achievement motivation will display responsible behaviour towards the task and there is a strong desire to be more effective in carrying out their duties. In line with Murray in Mangkunegara (2009: 68), who argues that the characteristics of people who have high achievement motivation are: (1) doing things as well as possible; (2) do something by achieving success; (3) completing tasks that require effort and skill; (4) desire to become a famous person and master a certain field; (5) doing difficult things with satisfactory results; (6) doing something very meaningful; and (7) do something better than other people [3]. Another important aspect is work environment. The efforts to improve the performances of lecturers can be done by providing a good working environment. A good work environment can support the implementation of work so that lecturers have a passion for work and can improve lecturers' performances. In line with the opinion of Nitisemito (in Agung, et al., 2012) which means that the work environment is everything that is around the worker, which can affect him in carrying out his duties [4].

Based on the background of the problem described above, the formulations of the problems in this study are is work environment affect achievement motivation?, is work environment affect performances of lecturers? and is achievement motivation affect performances of lecturers? The purposes of this study is to know the effect of work environment on achievement motivation, to know the effect of work environment on performances of lecturers and to know the effect of achievement motivation on performances of lecturers.

\section{Methods}

This study used survey method with path analysis and was done in Guidance and Counseling Department of Science Education Faculty at Universitas Negeri Medan. The sample were 25 lecturers. The instrument were questionnaires arranged in the positive statements based on Likert Scale model. The scorings are: always and strongly agree $=5$, often and agree $=4$, sometimes and doubtful $=3$, rarely and disagree $=2$, never and totally disagree $=1$. All questionnaires were developed based on the theories used from each variable. There are four indicators for performances of lecturers questionnaire, such as: (1) education and teaching, (2) conduct research, (3) community service, and (4) student guidance. The indicators will be interpreted in 33 items statement. There are eight indicators for work environment questionnaire, such as: (1) work atmosphere, (2) relationships with colleagues, (3) availability of work facilities, (4) lighting, (5) air circulation, (6) noise, (7) unpleasant odor, and (8) security. The indicators will be interpreted in 32 items statement. There are six indicators for achievement motivation questionnaire, such as: (1) have a high level of personal responsibility, (2) dare to take and take risks, (3) have realistic goals, (4) have a comprehensive work plan and strive to achieve goals, (5) utilizing concrete feedback on all activities undertaken, and (6) looking for opportunities to realize the plans that have been programmed. The indicators will be interpreted in 32 items statement.

To get a valid and reliable instrument, it is necessary to test the instrument. The trial was carried out by 25 lecturers outside the sample as much as possible according to the actual 
situation. The validity test is carried out only on the content and construct validity. Product Moment Correlation formula is used to calculate the validity and Alpha Cronbach formula is used to calculate reliability. Questionnaire items are declared valid if rcount $>$ rtable at the significant level of $5 \%$. After calculating, the validity result showed not all items are valid for every questionnaire and it can be seen in the following table.

Table 1. The Validity Results.

\begin{tabular}{llll}
\hline Variables & Total Items Tested & Items Not Valid & Items Valid \\
\hline Work Environment (X1) & 32 & 2 & 30 \\
Achievement Motivation (X2) & 32 & 2 & 30 \\
Performances of Lecturers (X3) & 33 & 2 & 31 \\
\hline
\end{tabular}

Questionnaire items are declared reliable if coefficient value $(\alpha)>$ reliability coefficient (0.70). The reliability result can be seen in following table.

Table 2. The Reliability Result.

\begin{tabular}{lll}
\hline \multicolumn{1}{c}{ Variables } & $\alpha$ & Category \\
\hline Work Environment (X1) & 0.900 & High reliability \\
Achievement Motivation (X2) & 0.883 & High reliability \\
Performances of Lecturers (X3) & 0.912 & High reliability \\
\hline
\end{tabular}

\section{Results and Discussion}

\subsection{Results}

Data Description. The summary can be seen in the following table

Table 3. Summary of Data Description of Each Research Variable.

\begin{tabular}{llll}
\hline Statistic Value & X1 & X2 & X3 \\
\hline Highest score & 145 & 135 & 144 \\
Lowest score & 40 & 36 & 38 \\
Mean & 95.30 & 87.34 & 94.37 \\
Standard deviation & 26.24 & 25.35 & 27.23 \\
Mode & 91.95 & 80.83 & 87.50 \\
Median & 93.81 & 84.50 & 91.25 \\
Ideal mean & 90 & 87 & 93 \\
Ideal standard deviation & 20.00 & 19.33 & 20.67 \\
\hline
\end{tabular}


Then, the presentation of the frequency distribution of each research variable

Work Environment (X1). The frequency distribution of work environment variable can be seen in the following table.

Table 4. Frequency Distribution of Work Environment Scores.

\begin{tabular}{lllll}
\hline Class & Class Interval & Observation Frequency & Relative Frequency & Category \\
\hline 1 & $30-60$ & 3 & $10.4 \%$ & Low \\
2 & $61-90$ & 8 & $32.2 \%$ & Less \\
3 & $91-121$ & 10 & $40.0 \%$ & Enough \\
4 & $122-150$ & 4 & $17.6 \%$ & High \\
& Total & 25 & $100 \%$ & \\
\hline
\end{tabular}

Achievement Motivation (X2). The frequency distribution of achievement motivation variable can be seen in the following table.

Table 5. Frequency Distribution of Achievement Motivation Scores.

\begin{tabular}{lllll}
\hline Class & Class Interval & Observation Frequency & Relative Frequency & Category \\
\hline 1 & $29-58$ & 4 & $16.0 \%$ & Low \\
2 & $59-88$ & 10 & $37.6 \%$ & Less \\
3 & $89-118$ & 8 & $32.8 \%$ & Enough \\
4 & $119-145$ & 3 & $13.6 \%$ & High \\
& Total & 25 & $100 \%$ & \\
\hline
\end{tabular}

Performances (X3). The frequency distribution of performances variable can be seen in the following table.

Table 6. Frequency Distribution of Performance Scores.

\begin{tabular}{lllll}
\hline Class & Class Interval & Observation Frequency & Relative Frequency & Category \\
\hline 1 & $31-62$ & 4 & $16.0 \%$ & Low \\
2 & $63-94$ & 9 & $35.2 \%$ & Less \\
3 & $95-126$ & 9 & $36.8 \%$ & Enough \\
4 & $127-155$ & 3 & $12.0 \%$ & High \\
& Total & 25 & $100 \%$ & \\
\hline
\end{tabular}

Normality test. To obtain a normal data distribution from each research variable, normality testing was carried out by using the Liliefors formula. Data for each research variable is called 
normally distributed, if Lcount < Ltable with a significance level of $5 \%$. A summary of the results of normality test for each variable can be seen in the following table.

Table 7. Summary of Normality Test.

\begin{tabular}{lcll}
\hline Research variable & $\mathrm{L}_{\text {count }}$ & $\mathrm{L}_{\text {table }}(\alpha=0.05) ; \mathrm{n}=25$ & Expalanation \\
\hline X1 on X2 & 0.074 & 0.08 & Normal Distribution \\
X1 on X3 & 0.050 & 0.08 & Normal Distribution \\
X2 on X3 & 0.065 & 0.08 & Normal Distribution \\
\hline
\end{tabular}

Linearity Test and Significance of Regression. Linearity test is used to determine the linear relationship between research variables and significance of regression is used to determine the significant relationship between research variables. The criteria for linearity test is Ho rejected Ha accepted, if Fcount $>$ Ftable with dk; $56: 67$. The summary of linearity test results can be seen in the following table.

Table 8. Summary of Linearity Test.

\begin{tabular}{llllll}
\hline Number & Correlation & $\mathrm{N}$ & $\mathrm{F}_{\text {count }}$ & $\mathrm{F}_{\text {table }}$ & Expalanation \\
\hline 1 & $\mathrm{X} 2$ over X1 & 25 & 32.27 & 3.86 & Linear \\
2 & $\mathrm{X} 3$ over X1 & 25 & 51.18 & 3.86 & Linear \\
3 & $\mathrm{X} 3$ over X2 & 25 & 112.54 & 3.86 & Linear \\
\hline
\end{tabular}

While the criteria for the significance of regression is Ho rejected Ha accepted, if Fcount $>$ Ftable with $\mathrm{dk} ; 1: 123$ at a significance level of 0.05 . The summary of significance of regression results can be seen in the following table.

Table 9. Summary of Significance of Regression.

\begin{tabular}{llllll}
\hline Number & Correlation & $\mathrm{N}$ & $\mathrm{F}_{\text {count }}$ & $\mathrm{F}_{\text {table }}$ & Expalanation \\
\hline 1 & $\mathrm{X} 2$ over X1 & 25 & 0.71 & 1.52 & Significant \\
2 & $\mathrm{X} 3$ over X1 & 25 & 1.08 & 1.52 & Significant \\
3 & $\mathrm{X} 3$ over X2 & 25 & 1.16 & 1.56 & Significant \\
\hline
\end{tabular}

Hypothesis Test. The calculation results of the correlation coefficient (r) between the research variables and the calculation results of the path coefficient $(\rho)$ between the research variables can be seen in the following table.

Table 10. Results of Correlation Coefficient and Path Coefficient.

\begin{tabular}{|c|c|c|c|c|c|c|}
\hline \multirow[t]{2}{*}{ Variables } & \multicolumn{3}{|c|}{ Correlation Coefficient } & \multicolumn{3}{|c|}{ Path Coefficient } \\
\hline & $\mathrm{r}_{\text {count }}$ & $t_{\text {count }}$ & $\mathrm{N}=25 ; \alpha=0,05$ & $\rho$ & $t_{\text {count }}$ & $\mathrm{N}=25 ; \alpha=0,05$ \\
\hline
\end{tabular}




\begin{tabular}{lllllll} 
X1 on X2 & 0.485 & 6.154 & 0.71 & 0.444 & 5.46 & Significant \\
X1 on X3 & 0.542 & 7.154 & 1.08 & 0.272 & 3.12 & Significant \\
X2 on X3 & 0.690 & 10.577 & 1.16 & 0.479 & 6.09 & Significant \\
\hline
\end{tabular}

From table 3.7, it can be concluded that three proposed hypotheses are accepted because tcount $>$ ttable. It means that the three path coefficients are significant. So, work environment (X1) can directly affect achievement motivation (X2), where the path coefficient is 0.444 or $19.4 \%$ and the correlation coefficient is 0.485 . Work environment (X1) can directly affect performances of lecturers (X3), where the path coefficient is 0.272 or $7.3 \%$ and the correlation coefficient is 0.542 . Achievement motivation (X2) can directly affect performances of lecturers (X3), where the path coefficient is 0.479 or $47.9 \%$ and the correlation coefficient is 0.690 .

\subsection{Discussion}

The Effect of Work Environment on Achievement Motivation. Based on the results of hypothesis testing, it shows that work environment has a positive and significant direct effect on achievement motivation. The path coefficient is 0.444 . This shows that work environment has an effect on achievement motivation. Thus, it can be concluded that work environment plays a very important role in increasing achievement motivation. This finding supports the theory from Colquitt, LePine and Wesson (2009: 8) that work environment has a direct effect on achievement motivation [5].

The Effect of Work Environment on Performances of Lecturers. Based on the results of hypothesis testing, it shows that work environment has a positive and significant direct effect on performances of lecturers. The path coefficient is 0.272 . This shows that work environment has an effect on performances. Thus, it can be concluded that work environment plays a very important role in improving performances. This finding supports the theory from Saydam (in Rahmawati, et al., 2014) defines that the work environment as the entire of work infrastructure that is around employees who are carrying out work that can affect the work itself [6]. This finding also supports the opinion from Ahyari (in Purnomo, 2014) states that the work environment is related to everything that is around work and can affect employees in carrying out their duties, such as employee services, working conditions, and employee relations within the company concerned [7].

The Effect of Achievement Motivation on Performances of Lecturers. Based on the results of hypothesis testing, it shows that achievement motivation has a positive and significant direct effect on performances of lecturers. The path coefficient is 0.479 . This shows that achievement motivation has an effect on performances. Thus, it can be concluded that achievement motivation plays a very important role in improving performances. These findings support the theory from Usman (2008: 259) that achievement motivation is an internal drive to overcome all obstacles and challenges in an effort to achieve goals [8]. 


\section{Conclusion}

Based on results of data analysis and discussion of research results, it can be concluded that work environment has a positive direct effect on achievement motivation with path coefficient of 0.444 or $19.4 \%$, work environment has a positive direct effect on performances of lecturers with path coefficient of 0.272 or $7.3 \%$, and achievement motivation has a positive direct effect on performances of lecturers with path coefficient of 0.479 or $47.9 \%$.

\section{References}

[1] Peraturan Pemerintah RI No. 60 Tahun 1999 tentang Pendidikan Tinggi. Jakarta: Presiden Republik Indonesia; 1999.

[2] United Nations Development Programme. Human Development Data Center. Available from: http://hdr.Undp.org/en/statistics [Accessed $1^{\text {st }}$ May 2021].

[3] Mangkunegara AA, Prabu A. Evaluasi Kinerja SDM. Bandung: Refika Aditama; 2009.

[4] Dhermawan AANB, et al. Pengaruh Motivasi, Lingkungan Kerja, Kompetensi dan Kompensasi Terhadap Kepuasan Kerja dan Kinerja Pegawai Di Lingkungan Kantor Dinas Pekerjaan Umum Provinsi Bali. J manajemen, strategi dan kewirausahaan. 2012; 6(2): 173-184.

[5] Colquitt JA, LePine JA, Wesson MJ. Organizational Behavior: Improving Performance and Commitment in The Workplace. New York: Mc. Graw-Hill Companies; 2009.

[6] Rahmawati NP, et al. Pengaruh Lingkungan Kerja Terhadap Kinerja Karyawan (Studi Pada Karyawan Kantor Pelayanan Pajak Pratama Malang Utara). J Adm Bisnis (JAB). 2014; 8(2): 1-9.

[7] Purnomo A. Pengaruh Motivasi Kerja Dan Lingkungan Kerja Terhadap Kepuasan Kerja Karyawan PT. Hyup Sung Indonesia Purbalingga. Yogyakarta: Universitas Negeri Yogyakarta; 2014.

[8] Usman H. Manajemen: Teori, Praktik, dan Riset Pendidikan. Jakarta: Bumi Aksara; 2008. 